\title{
The impact of corruption on analyst coverage.
}

\author{
HASSAN, O.A.G., GIORGIONI, G.
}




\title{
The Impact of Corruption on Analyst Coverage
}

\author{
Omaima A. G. Hassan and Gianluigi Giorgioni
}

Corresponding author:

Dr Omaima Hassan

Department of Accounting and Finance

Aberdeen Business School

Robert Gordon University

Aberdeen

AB10 7QB

Scotland, UK

Email: o.hassan@rgu.ac.uk

Phone: +44 (0)1224 263929

Gianluigi Giorgioni

The Management School

University of Liverpool

Chatham Street, L69 7ZH

Liverpool, UK

Tel: +44 (0) 1517950560

Email: G.Giorgioni@liverpool.ac.uk 


\title{
The Impact of Corruption on Analyst Coverage
}

\begin{abstract}
Purpose: This study investigates the impact of country-level corruption and firms' antibribery policies on analyst coverage. Analyst coverage has been identified as a powerful tool to detect fraud and should equally act as a possible tool to reduce corruption.
\end{abstract}

Design/methodology/approach: It employs a negative binomial count regression method on a longitudinal dataset of a sample of S\&P Global 1200 companies for the years 2010 to 2015. To control for potential endogeneity bias and improve the reliability of the estimation, both country-level corruption and firms’ anti-bribery policies variables were instrumented.

Findings: After controlling for potential endogeneity bias, the results show that the adoption of anti-bribery policies at firm level attract more analysts to follow a firm. The results for corruption at country level show that analyst coverage increases in less corrupted countries indicating that the costs of corruption exceed its potential benefits. When the variables corruption at country level and anti-bribery policies are interacted, the relationship is positive and highly significant.

Practical implications: Given the potential important role played by anti-corruption measures, firms are encouraged to adopt them to reduce the incidence of corruption and to increase analyst coverage which will reinforce the benign effect of monitoring.

Originality/value: Although the literature on corruption at the country level is rich, it is geared towards the determinants of corruption in contrast to its consequences, and fewer studies 
have focused on the impact of corruption at firm level due to data limitations. This paper addresses this gap and contributes to the literature on the consequences of corruption at firm level.

Keywords: analyst coverage; analysts following; sell-side analysts; corruption; anti-bribery policies, multi-country, S\&P Global 1200.

JEL: G12; G14; M4; G230; G240; M490; D73

Type: Research Paper 


\section{Introduction}

This study contributes to the growing literature on the impact of corruption. Judge et al. (2011) observe that the literature on corruption has been skewed towards examining the causes of corruption in contrast to its consequences as they observe that the number of papers published on the causes is twice as large as the number of papers published on the consequences of corruption. This paper reduces this gap in the literature by empirically examining the impact of corruption on analyst coverage. It investigates the impact of country-level corruption and firms’ anti-bribery policies on analyst coverage. Corruption at firm level can impact analyst coverage due to increased costs of information acquisition and costs associated with the revelation of corruption (Dyck et al., 2010). If a firm adopts anti-bribery policies, this may provide some assurance to analysts that the management is proactive in dealing with corruption at firm level. Corruption at country level can impact analyst coverage through increased levels of information costs, thereby reducing the number of analysts following. Alternatively, high levels of corruption at country level may induce the demand for analyst service for monitoring purposes, increasing thereby analyst coverage. Thus, the association between country-level corruption and analyst coverage depends on a trade-off between the costs and benefits associated with analyst coverage. The importance of analyst coverage is identified by Dyck et al. (2010) in table 2 page 2225, in the context of corporate fraud, as the second most effective fraud detectors within external governance, well ahead of other groups such as auditors and industry regulators. Therefore, it is important to examine the determinants of analyst coverage, related to the actions taken by companies to tackle corruption. To do so, this paper uses a novel panel dataset of a sample of S\&P Global 1200 companies for the years 2010 to 2015. This 
index represents $70 \%$ of global market capitalization, which provides good coverage and international reach as well as enhancing the generalizability of the results.

There are many definitions of corruption (e.g., Cuervo-Cazurra, 2016; Jain, 2001; Svensson 2003). Cuervo-Cazurra (2016, p. 36) defines corruption as the "abuse of entrusted power for private gains”. Entrusted power could originate from the government, shareholders, employees, trustees. Therefore, the abuse of entrusted power goes beyond the government and includes firms, international organisations, not-for-profit organisations and non-governmental organisations. Also, this definition indicates that people abuse that entrusted power for their own benefits at the cost of their organizations (Cuervo-Cazurra, 2016). Whether it is explicit in the form of bribes or implicit in the form of commission, corruption is perceived as a social evil and unethical practice that increases the hidden and real costs of doing business and can result in misallocation of resources (Alam, 1995; Kehoe, 1998; Dal Bó and Rossi; 2007; Chen et al., 2010). Corruption creates barriers to foreign direct investment, dislocates international trade and misleads public policy (Cuervo-Cazurra, 2006; Zhao et al., 2003). However, the consequences of corruption on the economic performance of firms is less clear (Jong and Ees, 2014; Cuervo-Cazurra, 2016) with a few studies (e.g., Wu, 2005; Chen et al., 2010) indicating that corruption increases the information asymmetry between the management and outside providers of funds, increasing thereby information costs.

On the other hand, following Bhushan's (1989) seminal paper, prior studies have investigated different determinants of analyst coverage at both firm and country levels including firm characteristics, corporate governance issues, levels of investor protection, cross-listing, dynamics of coverage, the quality of accounting standards and listing location (e.g., Bushman et al., 2004; Boubakri and Bouslimi, 2010; Yu, 2010; Chen et al., 2007; Giraldo, 2011; Abed 
et al., 2012; Kim and Shi, 2012, Hassan and Skinner, 2016). However, to date, there is a lack of direct empirical evidence on the association between analyst coverage and corruption, although corruption is perceived as a deterioration factor to the information environment and the economic performance of companies (e.g., Wu, 2005; Dal Bó and Rossi, 2007; Doh et al., 2003; Rodriguez et al., 2006; Uhlenbruck et al., 2006). In addition, although the literature on corruption is growing, it is mostly skewed towards examining the causes of corruption rather than its consequences (Judge et al., 2011). In this context, this study contributes to the literature in several aspects. It contributes to the literature on corruption by investigating the consequences of corruption at firm level. It also contributes to the literature on analyst coverage by extending the determinants of analysts following beyond firm characteristics to include firm policy and institutional factors. It postulates that the association between country-level corruption and analyst coverage depends on a trade-off between the benefits and costs associated with analyst coverage. In addition, while self-reported anti-bribery policies might not be enough to draw on their effectiveness in combating bribery and corruption at the firm level, it postulates that such policies may signal the serious commitment of the management to prevent, monitor and address corruption. It extends the work of Hassan and Giorgioni (2015) by utilising a more recent, longitudinal dataset in contrast to their cross-sectional analysis and controlling for potential endogeneity bias. In addition, the results of Hassan and Giorgioni (2015) are likely to suffer from selection bias because they limit their sample to companies with analyst coverage only, whereas companies that do not attract analyst coverage are excluded from their sample. In contrast, the current study performs a two-stage regression analysis utilising a panel dataset of a sample of S\&P Global 1200 companies for the years 2010 to 2015 to control for potential endogeneity bias in the estimation of the research model. In this dataset, the number of analysts following a company ranges from 0 to 63 . The use of panel data 
analysis provides many advantages over both the traditional cross-sectional and time-series analyses. It provides the researcher with a larger number of observations, increasing the degrees of freedom for any statistical testing and lessening the problem of multicollinearity among the explanatory variables (Hsiao, 2002), improving thereby the efficiency of estimates. In addition, prior studies on analyst coverage tend to apply variations of the classical linear regression model to datasets where the dependent variable (the number of analysts following) can only take non-negative integer values. In contrast, this study employs an econometric procedure that adjusts for the count nature of the dependent variable, as employed by Rock et al. (2001), Boubaker and Labégorre (2008) and Hassan and Skinner (2016), except that we apply the count data regression technique on a larger and more recent multi-country sample. Specifically, we employ a negative binomial count regression method to a sample of 5888 firm-year observations from 30 different countries. The current study also employs the Transparency International's Corruption Perception Index (CPI) as a proxy for corruption score at country level, which is typically used in prior studies (e.g., Yu, 2010; Chen et al., 2010, Judge et al., 2011). This index captures the perceptions of business people, academics, and risk analysts of the level of corruption at the country level. The CPI ranks countries based on how corrupt their public sector is perceived to be on a scale of 0 - 100, where 0 means that a country is perceived as highly corrupt and 100 means it is perceived as very clean. The CPI has been validated as a proxy for corruption at country level in prior studies (e.g., Wilhelm, 2002; Davis and Ruhe, 2003). After controlling for potential endogeneity bias in the variables of interest, the results show that the adoption of anti-bribery policies at firm level attract more analysts to follow a firm, in line with our hypothesis. The results for corruption at country level show that analyst coverage increases in less corrupted countries indicating that the costs of corruption exceed its 
benefits. When the variables corruption at country level and anti-bribery policies are interacted, the relationship is positive and highly significant.

The importance of the current study arises from the importance of analyst coverage to firm visibility. According to Arbel et al. (1983) and Merton (1987) neglected or less-visible firms are ones that are not followed by large numbers of financial analysts (investors) on a regular basis. Financial analysts increase the visibility of the firms they follow by signalling information about their performance, increasing thereby the demand for their common shares even when they do not actively add new information about these firms (Mola et al., 2013; Li and You, 2015). Also, higher analyst coverage may lead to the company being included either in industry reports or as an industry comparison in a report on a larger company, creating both visibility and credibility (Bushee and Miller, 2012). In addition, prior empirical studies suggest that higher ${ }^{1}$ analyst coverage is associated with lower transaction costs, higher stock liquidity, lower cost of capital and lower audit fees (e.g., Doukas et al., 2000; Jung et al., 2012; Lang et al., 2012; Easley and O'hara, 2004; Gotti et al., 2012). Therefore, it is not surprising that analyst coverage is actively pursued by firms. For example, Anantharaman and Zhang (2011) provide evidence that managers value analyst coverage and are willing to expend resources to maintain a particular level of that coverage. Also, Cliff and Denis (2004) find that firms are willing to

\footnotetext{
${ }^{1}$ However, analyst coverage may also have some negative effects on firm performance. For instance, He and Tian (2013) show that firms covered by a larger number of analysts generate fewer patents or patents with lower impact. The reason is that innovation involves a lengthy process that is full of uncertainty and has a high probability of failure, making the firm more vulnerable to, for example, hostile takeovers. As a reaction, managers tend to invest less in innovation and prioritise routine tasks that offer quicker and more certain returns, possibly sacrificing the long-term success of the firm.
} 
compensate for analyst coverage through initial public offerings premiums. Bushee and Miller (2012) note that some firms may resort to hiring investor relations professionals to pitch their business to analysts, and Kirk (2011) states that firms are prepared to buy paid-for research. Sibilkov et al. (2013) find that firms value analyst coverage and are prepared to strategically use the choice of appointments for mergers and acquisitions advisors to secure analyst coverage.

The remainder of this paper is organized as follows. Section 2 provides a brief discussion of the literature and develops the research hypotheses. Section 3 explains the research model. Section 4 describes the research samples and discusses the results. Section 5 provides concluding remarks.

\section{Literature review and hypotheses development}

Financial analysts collect a wide variety of information about the firms they follow, their industries and markets, analyze it and produce their reports. These reports may include buy, sell or hold recommendations, the competitive position of the firm relative to its rivals and analysts' forecasts of earnings and cash flows. According to the seminal paper of Bhushan's (1989), the equilibrium total expenditure by investors on analyst services for a particular firm in a given period is a function of the aggregate demand for and supply of analyst services.

Demand for analyst services arises in situations characterised by information asymmetry where agency problems can arise between managers and outside providers of funds. Analyst coverage helps mitigate these problems by providing information about the quality of investment opportunities to outside providers of funds and to the financial intermediaries they represent (Palepu et al., 2013). This information intermediary role of analysts goes beyond interpreting 
corporate disclosure to discovering new information and clarifying and confirming corporate disclosures (Huang et al., 2017). Chen et al. (2015) show how analysts help reducing the agency problem between shareholders and managers through direct and indirect monitoring. Analysts can provide a direct monitoring role through regular examination of the financial statements of the firms they follow and frequent interactions with the management via conference calls for example. They can also provide an indirect monitoring role through the dissemination of information to institutional investors and ordinary investors through research reports and media outlets such as newspapers and TV programs. Therefore, we expect that in a highly corrupt country, the monitoring role of analysts will be even more important, driving thereby the demand for analyst services and increasing analyst coverage. Alternatively, analysts themselves might be bribed to provide coverage (Cuervo-Cazurra, 2016).

However, higher level of corruption can also reduce analyst coverage due to increased level of information costs. According to Bhushan's (1989) model, the aggregate supply of outside analyst service is a function of the information costs they incur. The higher the information costs associated with following a specific company, the less likely that analysts will follow that company.

If country-level corruption is high, it is more likely that bribes and corruption will be perceived as normal ways of doing business even if this is illegal (Hauser and Hogenacker, 2014). According to transaction cost economics theory (Cuervo-Cazurra, 2016), operating in a corrupt country increases transaction costs because firms incur the costs of bribes to do business, in addition to the time and attention devoted by its employees to manage corrupt activates. However, bribes can also facilitate business activities and increase firms’ revenues. In addition, operating in a corrupt country increases uncertainty because managers are not sure whether 
they are bribing the right people, and whether they will receive the promised benefits of these bribes. Thus, the net impact of corruption on firms’ profitability depends on a trade-off between the costs and benefits associated with bribes. This, in turn, increases the level of uncertainty that analysts face in projecting future earnings and cash flows for these firms (Chen et al., 2010). In addition, managers who are engaged in corrupt practices will try to hide the bribe payments ( $\mathrm{Wu}, 2005)$, increasing thereby the level of information asymmetry between the management and outside providers of funds and market participants in general. This, in turn, makes it even harder for analysts to collect and process relevant information about the firms they follow to produce their reports. Moreover, high level of corruption may induce access to private information through bribes, reducing thereby the demand for outside analyst services.

Furthermore, Dal Bó and Rossi (2007) find that more corruption at the country level is strongly associated with more inefficient firms, in the sense that they employ more inputs to produce a given level of output. This, in turn, means that analysts will have to restate the financial statements to eliminate the effect of corruption, increasing thereby the costs of collecting and processing information. Following companies operating in highly corrupt countries can also increase the likelihood of financial loss for outside analysts if, for instance, they fail to provide an effective monitoring tool for stakeholders (Dyck et al., 2010). Karpoff et al. (2008) note that the largest monetary penalties inflicted to companies caught in corruption cases are not imposed by regulators or courts, but are imposed by the market, where presumably analyst coverage does play an important role. Karpoff et al. (2008) estimate that a quarter of the loss in market value is due to a re-assessment of the true financial situation of a firm (i.e. without the advantages obtained through corruption), but two-third are due to the loss of reputation as stakeholders of the company (e.g., investors, customers, and suppliers) modify the way they 
conduct business with the company. Legal costs only play a minor role (around 10\%) of the overall loss of stock market value.

Thus, the association between country-level corruption and analyst coverage depends on a trade-off between the costs and benefits associated with analyst coverage. If the benefits of the monitoring role of analysts in highly corrupt countries are higher (lower) than their associated costs, higher level of corruption will be associated with higher (lower) analyst coverage. Therefore, we develop our first hypothesis without estimating a direction of such association as a priori:

H1: there is an association between the level of corruption and the number of analysts following

Recent years have witnessed an international shift towards strengthening anti-corruption laws in many countries worldwide such as the US Foreign Corrupt Practices Act, the UK Bribery Act, the Council of Europe Criminal Law Convention on Corruption, the Canadian Corruption of Foreign Public Officials Act, among others. One aspect of these strengths is to criminally prosecute corruption practice by individuals and companies in their home countries even when the corrupt practice occurs abroad (Hauser and Hogenacker, 2014; Carr-Howard, 2014; Cuervo-Cazurra, 2016). Failure to adhere to such laws can result in serious reputational damage, significant fines, imprisonment of individuals, and debarment of organizations from conducting business with national and local governments (Carr-Howard, 2014). According to the neo-institutional theory, companies are motivated to address the norms, rules, and 
regulations that prevail in their respective external institutional environments ${ }^{2}$ to earn the legitimacy needed to operate in their societies (Baum and Oliver, 1991; Cuervo-Cazurra, 2016). In this context, firms can take a wide range of internal measures to tackle corruption and preserve its legitimacy. These measures are called firm-level controls of corruption and include, but not limited to, financial record keeping, statements by executive officers, internal monitoring, whistle-blowing facilities, use of compliance manuals, appointment of compliance officers or committees, threats of disciplinary actions and training for compliance, among others (Gordon and Miyake, 2001). Cuervo-Cazurra (2016) suggests future research to study the effectiveness of firm-level controls of corruption in reducing bribery by their managers. Adam and Rachman-Moore (2004) find that the social norms of the organization are perceived by employees to have the most influence on their conduct. Hauser and Hogenacker (2014) find that firms tend to follow a reactive approach toward the management of corruption risks in foreign countries and only implement anti-corruption measures if they have been confronted with the issue. Dyck et al. (2010) demonstrate that the incentives for the existing network of whistleblowers (auditors, analysts, and employees) are weak, thus it may be easier for the analyst just to drop coverage of companies involved in corrupt activities rather than revising their recommendations and developing a reputation of exposing corporate scandals (Young and Peng, 2013). While self-reported anti-bribery policies might not be enough to draw on their

\footnotetext{
${ }^{2}$ This gives rise to a potential ethical dilemma if the perceived norms, rules and regulations in dealing with corruption are different between the home and host countries. An example is a multinational business that has a headquarter in a highly clean country, but its subsidiaries operate in corrupt countries where the social norms about corruption could be very different. Although this is an interesting area for research, the focus in the current study is the anti-corruption policies that companies adopt in their respective home countries and their impact on analyst coverage.
} 
effectiveness in combating bribery and corruption at the firm level, the fact that a firm adopts and reports such policies may signal the serious commitment of the management to prevent, monitor and address corruption (Transparency International, 2009). In fact, recent empirical evidence shows that self-reported anti-corruption policies do reflect companies' real efforts to combat bribery and corruption and not merely cheap talk (Healy and Serafeim, 2013). Therefore, it is expected that firms that have signed such measures will have larger analyst coverage, hence the second research hypothesis is:

H2: the adoption of anti-bribery policies at firm level is expected to induce the number of analysts following a company

Another issue that worth investigating is whether the adoption of anti-bribery policies in firms that operate in highly corrupt countries would mitigate the impact of country-level corruption and induce analyst coverage. In other words, we examine the impact of the interaction term between corruption at country level and firms' self-reported anti-corruption policies on analyst coverage. Therefore, the third research hypothesis is:

H3: the presence of anti-bribery policies at firm level increases the number of analysts following a company that operates in a highly corrupt country.

\section{Research model}

Bhushan (1989) considers various company characteristics that impact the number of analysts following a firm such as ownership structure, firm size, and return variability. Following Bhushan (1989), the current study examines the impact of country-level corruption and firms' anti-bribery policies on analyst coverage, controlling for several firm-level and country-level 
factors. Therefore, the research model takes the following form (cross-section and time identifiers are suppressed for simplicity):

$$
\begin{gathered}
N O A=\beta_{0}+\beta_{1} A B P+\beta_{2} C P I+\beta_{3}(A B P * C P I)+\beta_{4} N I N S T+\beta_{5} I N S T+\beta_{6} I N S I D \\
+\beta_{7} M C A P+\beta_{8} V O L+\beta_{9} S E G+\beta_{10} \text { BETA }+\beta_{11} R O A+\beta_{12} G A A P \\
+\beta_{13} I N D U S T R Y+\beta_{14} C G O V+\beta_{15} G D P+\varepsilon
\end{gathered}
$$

However, it could be argued that analyst coverage could itself induce firms to change their behaviour. For instance, firms may be more inclined to adopt anti-bribery policies as a consequence of analyst coverage. Therefore, the variables $\mathrm{ABP}$ and NOA may be endogenously determined. Endogeneity may lead to biased results. Therefore, this paper employs a two-stage regression analysis to remove the problem of endogeneity between the adoption of anti-bribery measures (ABP) and analyst coverage. The instrumental variables are HRP and BEP (please see table 1 for more details). This study uses a popular measure for corruption at the country level, i.e. the Transparency International's Corruption Perception Index (CPI), which is typically used in prior studies (e.g., Yu, 2010; Chen et al., 2010) and has been validated against other alternative proxies of corruption in prior studies (e.g., Wilhelm, 2002; Davis and Ruhe, 2003). This index captures the perceptions of business people, academics, and risk analysts of the level of corruption at country level. However, some issues have been raised in the literature concerning the use of perception indexes in general (e.g., Olken, 2009; Razafindrakoto and Roubaud, 2010) and the CPI in particular (e.g., Bertrand and Mullainathan, 2001; Knack, 2007; Donchev and Ujhelyi, 2014). For example, the surveys document "expert opinions" of a small number of respondents (or perceptions of what "other firms” are doing) rather than their actual experience of corruption. Respondents may also be influenced by previous ratings or by recent events positive (recent economic performance) or 
negative (recent publicized corruption scandals). In addition, Donchev and Ujhelyi (2014) claim that economic development, political system, and cultural variables tend to bias perceptions of corruption away from experience. Furthermore, Fan et al. (2009) report that countries with similar levels of corruption frequency (gleaned from surveys) may have very different levels of corruption perceptions and vice versa. Moreover, the methodology for measuring the index has been changed in 2012, forcing a reduction in the number of observations that could be used. Therefore, we have re-estimated CPI with instrumental variables (FDI is the percentage of foreign direct investment net inflow to GDP and Openness is the imports of goods and services (\% of GDP)). This procedure could also allay the fear that the variable CPI (perception of corruption) on aggregate, may itself be influenced by the level of corruption of firms, which in itself could be influenced by analyst coverage. Variable definition and measurement are explained in Table 1.

\section{Insert Table 1 about here}

\section{DEPENDENT VARIABLES:}

NOA: The total number of analysts making recommendations for the security at the financial year-end.

\section{EXPLANATORY VARIABLES:}

ABP: A dummy variable to represent firms' self-reported anti-corruption policies. It takes the value of one if the company has policies in place to prevent corruption and zero otherwise.

CPI: The corruption score at the country level provided by Transparency International, which is typically used in prior studies, see Judge et al. (2011) for a review of papers that have used 
this measure. It reflects the perceived level of corruption at the country level, which aggregates information from multiple surveys into one indicator for the country (Cuervo-Cazurra, 2016, p. 38). It takes a value from 0 to 100 , where 0 means that a country is perceived as highly corrupt and 100 means it is perceived as very clean.

\section{FIRM-LEVEL CONTROL VARIABLES:}

Several firm-level controls are considered in the research model, namely: ownership structure (NINST; INST; INSID), firm size (MCAP), business complexity (SEG), return volatility (VOL; BETA), firm profitability (ROA), the quality of the accounting standards (GAAP) and industry-type (INDUSTRY). Where, NINST is the number of institutions holding shares in a company, and INST (INSID) is the percentage of institutional (insiders') holding in a company. According to Bhushan (1989) more concentrated institutional ownership (NINST; INST) may increase (decrease) the demand on in-house analyst services rather than outside analyst services if this is cost effective (ineffective) for individual institutional investors. In addition, a negative association between INSID and NOA is expected because insiders would have access to private information, reducing thereby the demand on outside analyst services (Bhushan, 1989).

Firm size (MCAP) is the market value of equity. SEG is the number of recorded business segments. Larger firms (MCAP) are expected to attract higher analyst coverage because they are widely held, have wider investors' bases with more potential transactions business to outside analysts. However, as the number of business segments (SEG) increases, the number of analysts following will decrease as the firm will become more complex and expensive to follow (Bhushan, 1989). 
VOL is the standard deviation of the relative price change for the 360 calendar days closing price, expressed as a percentage, while BETA is the market model beta for each stock measured via the market model using weekly data. Higher return volatility (VOL; BETA) implies higher uncertainty in predicting future returns. Thus, if outside analyst information is perceived to add valuable information over and above public information in predicting future returns, then higher return volatility is expected to increase the demand for outside analyst services (e.g., Bhushan, 1989; Hussain, 2000; Boubaker and Labégorre, 2008).

ROA is the return on assets to proxy for firm profitability. Prior empirical studies suggest that analysts will be reluctant to follow less profitable companies (e.g., Boubaker and Labégorre, 2008), implying a positive association between ROA and NOA. Furthermore, we include a dummy variable (GAAP), takes the value of 1 if the country applies US accounting standards or international financial reporting standards (IFRS) and 0 otherwise, to proxy for the quality of the accounting standards applied by the sample firms, where high-quality accounting standards are expected to attract more analyst coverage (e.g., Kim and Shi, 2012). In addition, the quality of the accounting standards might also be associated with the extent of the perceived corruption at country level since Khalil et al. (2015) find that firms are less likely to grant gift to secure a government contract in countries having more extensive financial reporting requirements. Also, we include industry dummies (INDUSTRY) that takes the value of 1 for the relevant industry and 0 otherwise to control for the type of industry.

\section{COUNTRY-LEVEL CONTROL VARIABLES:}

CGOV is the governance index at country level, which is developed using the principal component analysis. It is the first principal component of all corporate governance indicators at country level except the control of corruption indicator. It explains $75 \%$ of the variation in 
the corporate governance indicators. It is expected that better corporate governance environment will attract more analyst coverage. Alternatively, in a bad corporate governance environment, there is more demand for the monitoring role of outside analysts. GDP is the gross domestic product per capita to measure country income.

\section{Sample and Results}

\subsection{Research sample}

This study examines the impact of corruption on analyst coverage utilising a sample of S\&P Global 1200 companies from 2010 to 2015. The S\&P Global 1200 index represents 70\% of global market capitalization, which is likely to offer good variation in the variables of interest and has international reach. The S\&P Global 1200 consists of 7 indices, many of which are accepted leaders in their regions. These include the S\&P 500 (US), S\&P Europe 350, S\&P TOPIX 150 (Japan), S\&P/TSX 60 (Canada), S\&P/ASX All Australian 50, S\&P Asia 50 and S\&P Latin America 40. According to the OECD (2014), most international bribes are paid by large companies to win contracts in advance economies rather than in the developing world, and that most bribe payers and takers are from wealthy countries, which justifies the choice of our sample and setting.

We collected data for the constituents of S\&P Global 1200 for the years 2010 to 2015 deliberately avoiding the recent financial crisis of 2008/09. Data at the firm level are collected from Bloomberg database. Data on the Corruption Perception Index scores (CPI) are obtained from Transparency International database. Data on gross domestic product per capita, foreign direct investments, corporate governance indicators, and imports of goods and services to GDP are obtained from the World Bank. This has yielded an initial sample of 1187 companies for the years 2010 to 2015 with 7122 firm-year observations. However, the final sample size 
depends on data availability for each variable included in the model. It is worth noting that Transparent International has changed its methodology in calculating corruption score in 2012. The final common sample consists of 1050 firms covering 30 different countries for the years 2010 to 2015 with 5888 firm-year observations. Table 2 shows a breakdown of the sample by country. Interestingly, countries like South Africa and China that are at the lower end of the GDP and CPI spectrums attract higher than average analyst coverage. This table also tells an interesting story about the average of analyst coverage, corruption and GDP, which goes against intuition or common sense. For example, a country like China has an average GDP per capita of 5,533 USD with corruption score (CPI) of 24 but attracts higher than average analyst coverage (29), whereas a country like Australia has an average GDP per capita of 53,363 USD with a corruption score of 81 but attracts less than average analyst coverage of 15 . Another example, countries like South Africa and Austria, and Brazil and Chili have the same average number of analyst following but they have significantly different levels of corruption. A third example is that it is not the US but South Korea that attracts the highest average number of analyst coverage. Thus, the perception that highly clean countries would attract more analyst coverage is not observed from these figures which highlights that the association between analyst coverage and the extent of corruption is an empirical issue.

\section{Insert Table 2 about here}

\subsection{Results and Discussion}

Table 3 Panel A shows the descriptive statistics of all the variables. It shows that the average company in the research sample comes from a moderately clean country with a CPI score of 74 and an average GDP of 46,851 USD. It also shows that $62 \%$ of the sample firms have 
policies in place to tackle corruption at the firm level. The ownership structure of a typical firm in the sample is $66 \%$ institutional holding (INST) and less than $2 \%$ insiders holding (INSID). The average number of analysts following a firm (NOA) is about 22 with an average number of 633 institutions holdings (NINST). Market capitalization (MCAP) for a typical firm is on average 28,361 million USD. Average return variability (VOL) is 31 and market beta (BETA) is 1 on average. A typical firm has 4 segments (SEG) on average and an average return on assets (ROA) of 5\%. About $89 \%$ of the sample firms apply either US accounting standards or IFRS.

Panel B of Table 3 shows the pair-wise correlation matrix. The correlations do not identify any need for concerns about multicollinearity since most correlations are quite weak. The results show no correlation between NOA and CPI in contrast to hypothesis no 1. However, they show that the higher the probability that a firm adopts an anti-bribery policy (ABP), the higher the number of analysts following it, consistent with hypothesis no 2.

\section{Insert Table 3 about here}

Table 3 also shows that the number of analysts following (NOA) is positively associated with the number of institutions holding shares in a company (NINST), firm size (MCAP), firm profitability (ROA), and the quality of accounting standards (GAAP) consistent with results from prior studies (e.g., Bhushan, 1989; Hussain, 2000; Boubaker and Labégorre, 2008; Kim and Shi, 2012). The association between the number of analysts following and the number of recorded segments (SEG) is positive and significant, contrary to expectations, indicating higher analyst coverage for more complex companies. Table 3 also shows a negative and significant correlation between NOA and the percentage of institutional holdings (INST) indicating that 
higher percentage of institutional holdings motivates more reliance on the service of in-house analysts rather than outside analysts (Bhushan, 1989). Furthermore, Table 3 also shows a negative and significant association between analyst coverage and return volatility (VOL) inconsistent with prior expectations. However, these findings reflect pair-wise correlations only, a multi-regression analysis could yield different results.

Table 4 reports the results for the research model explaining analyst coverage. The estimation is based on a count regression model that better suits an integer dependent variable, after controlling for heteroscedasticity.

\section{Insert Table 4 about here}

Ordinary least squares (OLS) assumes that the dependent variable is continuous where clearly our dependent variable, i.e. NOA, is a count integer taking on values from 0 to 63 . Using OLS in this context can lead to biased and inconsistent estimates (Long and Freese, 2006), therefore we rely on a count regression method to predict analyst coverage. Poisson model is a count regression model which corrects for the discrete, count data nature of the dependent variable and is especially suitable when the (conditional) mean and variance of the dependent variable are equal. If the equality of the (conditional) mean and variance does not hold, then the standard errors generated by a maximum likelihood of the Poisson will be underestimated thereby conveying incorrectly high level of significance, in such case a negative binomial count (NBC) regression method is more suitable (Rock et al., 2000). In this paper, a negative binomial count regression method is used. Since endogeneity is an issue for our research model, we use twostage regression analysis to control for this potential bias. We run the analysis with one and two estimated variables and compare the results. 
Table 4 shows the results of the second-stage regression model after estimating each of ABP and CPI using instrumental variables in results not tabulated. It shows that the results seem to strongly indicate that firms operating in a highly clean country (measured by high levels of the variable CPI) attracts fewer analysts, once the effect of presence of the anti-bribery policy (and the control variables) is taken into consideration. This appears to be quite a consistent finding. This finding contradicts results from Chen et al. (2010) that operating in corrupt countries makes it harder for analysts to predict firms' future earnings and cash flows. However, once the variable CPI is replaced by estimated instrumental variable, the relationship becomes positive. The results also show that adopting anti-bribery policies at the firm level (ABP) has a positive and significant association with analyst coverage consistent with hypothesis no 2 . This finding supports recent empirical evidence by Healy and Serafeim (2016) that selfreported anti-corruption policies reflect a genuine commitment by companies to combat bribery and corruption at firm level and not merely cheap talks, thus induce high analyst coverage. Finally, the results of the interaction term capturing the effect of operating in a less corrupt country and the adoption of anti-bribery depend upon the choice of the variable approximating corruption. With the CPI index, the adoption of anti-corruption policies does not induce analyst coverage, rejecting thereby hypothesis no 3. However, if the estimated CPI variable is used, anti-corruption policies appear to induce analyst coverage, in line with hypothesis no 3.

In terms of the control variables the results are remarkably consistent regardless of the choice of variable CPI. Analyst coverage (NOA) is significantly and positively associated with the number of institutional investors (NINST), firm size (MCAP), market beta (BETA) and the quality of accounting standards (GAAP) consistent with results prior studies (e.g., Bhushan, 1989; Hussain, 2000; Rock et al., 2000; Boubaker and Labégorre, 2008; Kim and Shi, 2012). 
NOA is also significantly and positively (negatively) associated with CGOV (GDP). Consistent with results from prior studies, NOA is negatively associated with business complexity (SEG) (e.g., Bhushan, 1989; Rock et al., 2000). Surprisingly, firm profitability (ROA) is negatively associated with NOA. This result indicates more analyst coverage for less profitable firms unlike results from prior studies (e.g., Boubaker and Labégorre, 2008). This is potentially due to less profitable firms having more volatile stock returns, as can be seen from the negative and significant association between ROA and each of VOL and BETA in Table 3, which induces more demand on outside analyst service.

Finally, Khalil et al. (2015) find that firms are less likely to bribe bureaucrats in countries which have more extensive financial reporting requirements and those where audit firms face a higher litigation and sanction risk. At the firm level, Khalil et al. (2015) find that firms are less likely to bribe bureaucrats when their financial statements are reviewed by an external audit firm. Taken together, the results of Khalil et al. (2015) might indicate that the current analysis is prone to omitted variable bias $^{3}$. Thus, as a robustness check, we re-run the analysis after

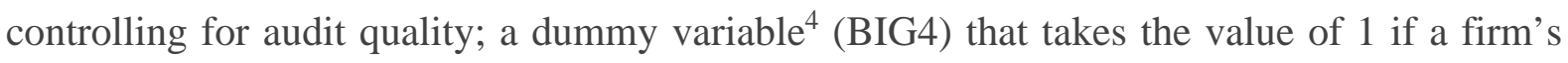
accounts are audited by one of the big four audit firms and 0 otherwise, and the business extent of disclosure (DISC), a disclosure index of the business extent of disclosure at the country-

\footnotetext{
${ }^{3}$ We would like to thank an anonymous referee for this suggestion. The results of this extra regression are not included in the paper for reasons of space, but are available, upon request, from the authors.

${ }^{4}$ auditor size is often used in prior studies as a surrogate of audit quality (e.g. Tendeloo and Vanstraelen, 2008; Chen et al., 2011). This line of research might be interpreted as either larger auditors provide higher quality audits as they have more wealth and reputation at risk (DeAngelo, 1981), or smaller auditors supplying unacceptably low levels of audit quality (DeFond and Francis, 2005). Smaller audit firms report less conservatively (issue fewer non-clean audit reports), and their clients are more likely to have abnormal accruals, which is suggestive of more aggressive earnings management.
} 
level provided by the World Bank, in results not tabulated to test the consistency of our results. It is also worth noting that the quality of accounting standards at the firm level is considered using GAAP, and the quality of the governance and monitoring roles at the country level are considered using CGOV. Our main results continue to hold after the inclusion of both BIG4 and DISC in the analysis. Also, the BIG4 variable was interacted with the variable capturing governance rules at country level (CGOV). The results were in line with the previous findings. Furthermore, we test whether the three variables of interest, i.e. ABP, CPI and ABP*CPI, are redundant and might thus be deleted from the research model, in results not tabulated, after accounting for the several firm-level and country-level controls including BIG4. The redundant variable hypotheses are rejected for any pair of these variables and for the three variables jointly, which indicates that these variables are significant estimators of the number of analysts following a company.

\section{Concluding remarks}

This study investigates the impact of corruption at country level and firm's action to tackle corruption on analyst coverage employing a negative binomial count regression method for a sample of S\&P Global 1200 companies for the years 2010 to 2015. To remove the issue of endogeneity and improve the reliability of the variable corruption, both variables corruption perception (CPI) and anti-bribery policies (ABP) were instrumented. The results are affected by the choice of corruption index. However, they show that the adoption of anti-bribery policies at firm level attract more analysts to follow a firm, in line with our hypothesis. However, firms operating in countries with higher levels of corruption appear to attract higher analyst coverage, consistent with the importance of the monitoring role of analyst coverage in highly corrupt countries, only if the corruption perception index is used. Once the CPI is estimated by 
instrumental variables, the relationship is in line with the transaction cost hypothesis that analyst coverage increases in less corrupted countries. The same conclusion applies to the case when the variables corruption at country level and anti-bribery policies are interacted. The relationship is strongly positive and significant in the case of the instrumented CPI.

The findings of this paper have several important implications. Firstly, the results of the current study provide robust evidence that proactive actions by firms, such as the adoption of antibribery policies, can initiate or strengthen a positive process of increased analyst coverage leading to higher degrees of monitoring. Given the significant role played by analysts in uncovering fraud, as documented by Dyck et al. (2010), this is an important finding. Secondly, this paper also contributes to the extant literature on corruption by providing empirical evidence on the consequences of corruption at firm level, rather than the causes of corruption. This is an important contribution because there is a serious imbalance between the number of papers examining the causes of corruption than its consequences as observed by Judge et al. (2011). Thirdly, this study also contributes to the literature on the determinants of analyst coverage by extending the determinants of analysts following beyond firm characteristics to include firm policy and institutional factors. This contribution is particularly crucial at a time when investment firms are now required to clearly state the costs of any investment advice they may provide because of the recent introduction of the new regulatory framework contained in the European Union Market in Financial Instruments Directive and Regulation (MiFID II). Investment firms are required to inform clients whether the investment advice is provided on an independent basis to ensure that clients are not sold inappropriate products, and that inducements are only allowed if they benefit the client (Lannoo, 2017). The paper also sheds an important light on the consequences of the adoption of anti-corruption measures at firm 
level such as anti-bribery policies. One practical implication is to encourage firms to adopt anti-corruption measures to reduce the incidence of corruption and increase analyst coverage. This result is particularly timely and practically relevant since the new European Directive 2014/95/EU requires large companies to include non-financial information about anticorruption and bribery in their annual reports from 2018 onwards. A political implication is to expand efforts to produce reliable and consistent controls of corruption across companies and countries, perhaps through the introduction of compulsory anti-bribery measures. Finally, the paper establishes both theoretical and empirical links between two strands of research, i.e. analyst coverage and corruption, which may provide new material to incorporate in the syllabus of some courses in finance and motivate future research on the determinants and consequences of the adoption of anti-corruption and bribery measures at firm level.

\section{Acknowledgement}

The authors thank two anonymous referees for their constructive feedback, as well as delegates who provided feedback at the research seminar series at the Robert Gordon University, Aberdeen Business School October 2017, and the Annual Congress of the European Accounting Association 2018, Milan, Italy. Remaining errors are the responsibility of the authors.

\section{References}

Abed, A., Abdallah, W. and Ismail, A. (2012), "Do accounting standards matter to financial analysts? An empirical analysis of the effect of cross-listing from different accounting standards regimes on analyst following and forecast error”, The International Journal of Accounting, Vol. 47, pp. 168-97.

Adam, A. M. and Rachman-Moore, D. (2004), "The methods used to implement an ethical code of conduct and employee attitudes", Journal of Business Ethics, Vol. 54, pp. 225-244. 
Alam, M.S. (1995), "A theory of limits on corruption and some applications", Kyklos, Vol. 48, No. 3, pp. 419-435.

Anantharaman, D. and Zhang, Y. (2011), "Cover me: Managers' responses to changes in analyst coverage in the Post-Regulation FD period", The Accounting Review, Vol. 86, pp. 18511885.

Arbel, A., Carvell, S. and Strebel, P. (1983), "Giraffes, Institutions and Neglected Firms", Financial Analysts Journal, pp. 2-8.

Baum, J.A.C. and Oliver, C. (1991), "Institutional linkages and organizational mortality", Administrative Science Quarterly, Vol. 36, pp. 187-218.

Bertrand, M. and Mullainathan, S. (2001), "Do people mean what they say? Implications for subjective survey data", The American Economic Review, Vol. 91, pp. 67-72.

Bhushan, R. (1989), "Firm characteristics and analyst following", Journal of Accounting and Economics, Vol. 11, pp. 255-74.

Boubaker, S. and Labégorre, F. (2008), "Ownership structure, corporate governance, and analyst following: A study of French listed firms", Journal of Banking and Finance, Vol. 32, pp. 961-76.

Boubakri, N. and Bouslimi, L. (2010), "Analyst following of privatized firms around the world: The role of institutions and ownership structure", The International Journal of Accounting, Vol. 45, pp. 413-42.

Bushee, B. J. and Miller, G. S. (2012), "Investor relations, firm visibility, and investor following", The Accounting Review, Vol. 87, pp. 867-97.

Bushman, R. M., Piotroski, J. D. and Smith, A. J. (2004), "What determines corporate transparency?", Journal of Accounting Research, Vol. 42, pp. 207-52.

Carr-Howard, M. (2014), "Global Anti-Corruption Laws: An Executive Summary, Dentons", Available online

at: file://C:/Users/Omaima/Downloads/Global\%20AntiCorruption\%20Laws\%20Dentons\%20(3 ).pdf, (Accessed 05/01/ 2018).

Chen, C. J., Ding, Y. and Kim, C. F. (2010), "High-level politically connected firms, corruption, and analyst forecast accuracy around the world", Journal of International Business Studies, Vol. 41, pp. 1505-1524.

Chen, F., Weiss, I. S. and Zheng, L. (2007), "The predictive role of analyst coverage intensity: evidence from cross-listing in the US", Journal of Contemporary Accounting and Economics, Vol. 3, pp. 34-57. 
Chen, H., Chen, J. Z., Lobo, G. J., and Wang, Y. (2011). "Effects of Audit quality on earnings management and cost of equity capital: Evidence from China", Contemporary Accounting Research, Vol. 28, No. 3, pp. 892-925.

Chen, T., Harford, J. and Lin, C. (2015), "Do analysts matter for governance? Evidence from natural experiments", Journal of financial economics, Vol. 115, pp. 383-410.

Cliff, M. T. and Denis, D. J. (2004), "Do initial public offering firms purchase analyst coverage with underpricing?", The Journal of Finance, Vol. 59, pp. 2871-2901.

Cuervo-Cazurra, A. (2006), "Who cares about corruption?", Journal of International Business Studies, Vol. 37, No. 6, pp. 807-822.

Cuervo-Cazurra, A. (2016), "Corruption in international business", Journal of World Business, Vol. 51, 35-49.

Dal Bó, E. and Rossi, M. A. (2007), "Corruption and inefficiency: Theory and evidence from electric utilities", Journal of Public Economics, Vol. 91, pp. 939-962.

Davis, J. H. and Ruhe, J.A. (2003), "Perceptions of country corruption: Antecedents and outcomes", Journal of Business Ethics, Vol. 43, No. 4, pp. 275-288.

DeAngelo, L. (1981). "Auditor size and quality", Journal of Accounting and Economics, December, pp. 183-199.

DeFond, M.L., and Francis, J.R. (2005). "Audit research after Sarbanes-Oxley", Auditing: A Journal of Practice and Theory, Vol. 24, (Supplement), pp. 5-30.

Doh, J. P., Rodriguez, P., Uhlenbruck, K., Collins, J. and Eden, L. (2003), "Coping with corruption in foreign markets", The Academy of Management Executive, Vol. 17, pp. 114-127.

Donchev, D. and Ujhelyi, G. (2014), "What do corruption indices measure?", Economics and Politics, Vol. 26, No. 2, pp. 309-331.

Doukas, J. A., Kim, C. and Pantzalis, C. (2000), "Security analysis, agency costs, and company characteristics", Financial Analysts Journal, Vol. 56, pp. 54-63.

Dyck, A., Morse, A. and Zingales, L. (2010), "Who blows the whistle on corporate fraud?", The Journal of Finance, Vol. 65, pp. 2213-2253.

Easley, D. and O'hara, M. (2004), "Information and the cost of capital", The Journal of Finance, Vol. 59, pp. 1553-1583. 
Fan, C. S., Lin, C. and Treisman, D. (2009), "Political decentralization and corruption: Evidence from around the world", Journal of Public Economics, Vol. 93, pp. 14-34.

Giraldo, M. (2011), "Dynamics of analysts' coverage and the firms' information environment", International Review of Financial Analysis, Vol. 20, pp. 345-354.

Gotti, G., Han, S., Higgs, J. L. and Kang, T. (2012), "Managerial stock ownership, analyst coverage, and audit fee", Journal of Accounting, Auditing and Finance, Vol. 27, pp. 412-437.

Gordon, K. and Miyake, M. (2001), "Business approaches to combating bribery: A study of codes of conduct", Journal of Business Ethics, Vol. 34, pp. 161-174.

Hassan, O. A. G. and Skinner, F. (2016), "Analyst coverage: Does the listing location really matter?", International Review of Financial Analysis, Vol. 46, pp. 227-236.

Hassan, O. A. G. and Giorgioni, G. (2015), "Analyst coverage, corruption and financial secrecy: A multi-country study", Working paper, Available at SSRN: https://ssrn.com/abstract=2566848 or http://dx.doi.org/10.2139/ssrn.2566848, (Accessed, 10/01/2018).

Huang, A.H., Lehavy, R., Zang, A.Y. and Zheng, R. (2017), "Analyst Information Discovery and Interpretation Roles: A Topic Modeling Approach", Management Science, doi: 10.1287/mnsc.2017.2751.

Hauser, C. and Hogenacker, J. (2014), "Do firms proactively take measures to prevent corruption in their international operations?", European Management Review, Vol. 11, pp. 223237.

He, J. J. and Tian, X. (2013), "The dark side of analyst coverage: the case of innovation", Journal of Financial Economics, Vol. 109, No. 3, pp. 856-78.

Healy, P. M. and Serafeim, G. (2016), "An analysis of firms' self-reported anti-corruption efforts", The Accounting Review, Vol. 91, No. 2, pp. 489-511.

Hsiao, C. (2002), Analysis of Panel Data, $2^{\text {nd }}$ Edition, Cambridge University Press, London.

Hussain, S. (2000), "Simultaneous determination of UK analyst following and institutional ownership", Accounting and Business Research, Vol. 30, pp. 111-124.

Jain, A. K. (2001), "Corruption: a review", Journal of Economic Surveys, Vol. 15, pp. 71-121.

Jong, G. and Ees, H. (2014), "Firms and Corruption", European Management Review, Vol. 11, pp. 187-190.

Judge, W. Q., Mcnatt, D. B. and Xu, W. (2011), "The antecedents and effects of national corruption: A meta-analysis", Journal of World Business, Vol. 46, pp. 93-103. 
Jung, B., Sun, K. J. and Yang, Y. S. (2012), "Do financial analysts add value by facilitating more effective monitoring of firms' activities?", Journal of Accounting, Auditing and Finance, Vol. 27, pp. 61-99.

Khalil, S., Saffar, W. and Trabelsi, S. (2015). "Disclosure standards, auditing infrastructure, and bribery mitigation". Journal of Business Ethics, Vol. 132, No. 2, pp.379-399.

Karpoff, J. M., Lee, D. S. and Martin, G. S. (2008), "The cost to firms of cooking the books", Journal of Financial and Quantitative Analysis, Vol. 43, pp. 581-611.

Kehoe, W.J. (1998), "The environment of ethics in global business", Journal of Business and Behavioral Sciences, Vol. 2, (Fall), pp. 47-56.

Kim, J.-B. and Shi, H. (2012), "Voluntary IFRS adoption, analyst coverage, and information quality: International evidence", Journal of International Accounting Research, Vol. 11, pp. 45-76.

Kirk, M. (2011), "Research for sale: Determinants and consequences of paid-for analyst research", Journal of financial economics, Vol. 100, pp. 182-200.

Knack, S. (2007), "Measuring corruption: A critique of indicators in Eastern Europe and Central Asia", Journal of Public Policy, Vol. 27, pp. 255-291.

Lang, M., Lins, K. V. and Maffett, M. (2012), "Transparency, liquidity, and valuation: International evidence on when transparency matters most", Journal of Accounting Research, Vol. 50, pp. 729-774.

Lang, M. H. and Lundholm, R. J. (1996), "Corporate disclosure policy and analyst behavior", The Accounting review, pp. 467-492.

Lannoo, K. (2017). MiFID II and the new market conduct rules for financial intermediaries: Will complexity bring transparency? European Capital Markets Institute, Available at: https://www.ceps.eu/publications/new-market-conduct-rules-financial-intermediaries-willcomplexity-bring-transparency, (Accessed 27/07/2018).

Li, K. K. and You, H. (2015), "What is the value of sell-side analysts? Evidence from coverage initiations and terminations", Journal of Accounting and Economics, Vol. 60, Nos 2-3, pp. 141-160.

Long, J. S. and Freese, J. (2006), Regression models for categorical dependent variables using Stata, Stata press, Texas.

Merton, R. (1987), "A simple model of capital market equilibrium with incomplete information", Journal of Finance, Vol. 42, pp. 483-510. 
Mola, S., Rau, P. R. and Khorana, A. (2013), "Is There Life after the Complete Loss of Analyst Coverage?", The Accounting Review, Vol. 88, No. 2, pp. 667-705.

OECD (2014), Foreign Bribery Report: An Analysis of the Crime of Bribery of Foreign Public Officials, OECD Publishing, http://dx.doi.org/10.1787/9789264226616-en, (Accessed 30/02/2018).

Olken, B. A. (2009), "Corruption Perceptions vs. Corruption Reality", Journal of Public Economics, Vol. 93, pp. 950-964.

Razafindrakoto, M. and Roubaud, F. (2010), "Are international databases on corruption reliable? A comparison of expert opinion surveys and household surveys in sub-Saharan Africa", World Development, Vol. 38, pp. 1057-1069.

Rock, S., Sedo, S. and Willenborg, M. (2001), "Analyst following and count-data econometrics", Journal of Accounting and Economics, Vol. 30, pp. 351-373.

Rodriguez, P., Siegel, D. S., Hillman, A. and Eden, L. (2006), "Three lenses on the multinational enterprise: Politics, corruption, and corporate social responsibility", Journal of International Business Studies, Vol. 37, pp. 733-746.

Serafeim, G. (2014), "Firm competitiveness and detection of bribery", Harvard Business School, Working Paper 14-012, available http://www.hbs.edu/faculty/Publication\%20Files/14-012_42a7455b-4a8a-4393-a16a18b0de5278ba.pdf, (Accessed 05/07/ 2017).

Sibilkov, V., Straska, M. and Waller, H. G. (2013), "Do firms use M\&A business to pay for analyst coverage?", Financial Review, Vol. 48, pp. 725-751.

Svensson, J. (2003), "Who must pay bribes and how much? Evidence from a cross section of firms", The Quarterly Journal of Economics, pp. 207-230.

Tendeloo, B.V., and Vanstraelen, A. (2008). "Earnings management and audit quality in Europe: Evidence from the private client segment market", European Accounting Review, Vol. 17, No. 3, pp. 447-469.

Transparency International (2009), Transparency in Reporting on Anti-Corruption: A Report on Corporate Practices, Transparency International, Berlin.

Uhlenbruck, K., Rodriguez, P., Doh, J. and Eden, L. (2006), "The impact of corruption on entry strategy: Evidence from telecommunication projects in emerging economies", Organization Science, Vol. 17, pp. 402-414.

Wilhelm, P.G. (2002), "International validation of the Corruption Perceptions Index: Implications for business ethics and entrepreneurship education", Journal of Business Ethics, Vol. 35, No. 3, pp. 177-189. 
Wu, X. (2005), "Corporate governance and corruption: A cross-country analysis", Governance: An International Journal of Policy, Administration, and Institutions, Vol. 18, pp. 151-170.

Young, S. M. and Peng, E. Y. (2013), "An analysis of accounting frauds and the timing of analyst coverage decisions and recommendation revisions: Evidence from the US", Journal of Business Finance and Accounting, Vol. 40, pp. 399-437.

Yu, M. (2010), "Analyst forecast properties, analyst following and governance disclosures: A global perspective", Journal of International Accounting, Auditing, and Taxation, Vol. 19, pp. $1-15$.

Zhao, H., Kim, S. and Du, J. (2003), "Corruption, transparency and foreign direct investment: A cross-country analysis”, Management International Review, Vol. 43, No. 1, pp. 41-63. 
Table 1: A summary of variable measurement

This table reports the definition of the different variables.

\begin{tabular}{|c|c|}
\hline Variable & Definition \\
\hline NOA & The total number of analysts making recommendations for the security at the financial year-end. \\
\hline CPI & $\begin{array}{l}\text { The corruption score at the country level provided by Transparency International. It takes a value from } \\
0 \text { to } 100 \text {, where } 0 \text { means that a country is perceived as highly corrupt and } 100 \text { means it is perceived } \\
\text { as very clean. }\end{array}$ \\
\hline ABP & $\begin{array}{l}\text { It represents firms' self-reported anti-corruption policies. It is a dummy variable that takes the value } \\
\text { of one if the company has policies in place to prevent corruption and zero otherwise. }\end{array}$ \\
\hline HRP & $\begin{array}{l}\text { A dummy variable that takes the value of } 1 \text { if the company has implemented any initiatives to } \\
\text { ensure the protection of the rights of all people it works with, and } 0 \text { if the company has not explicitly } \\
\text { disclosed any such efforts in its Annual or Company Responsibility reports. }\end{array}$ \\
\hline BEP & $\begin{array}{l}\text { A dummy variable which takes the value of } 1 \text { if the company has established ethical guidelines } \\
\text { and/or a compliance policy for its non-management/executive employees in the conduct of } \\
\text { company business, and } 0 \text { if the company has not explicitly disclosed this policy in its Annual or } \\
\text { Company Responsibility Reports. }\end{array}$ \\
\hline FDI & The percentage of foreign direct investment net inflow to GDP. \\
\hline Openness & Imports of goods and services (\% of GDP). \\
\hline NINST & The number of institutions holding shares in a company. \\
\hline INST (INSID) & The percentage of institutional (insiders') holding in a company. \\
\hline MCAP & The market value of equity of the firm at the fiscal year-end. \\
\hline SEG & The number of recorded business segments. \\
\hline VOL & $\begin{array}{l}\text { The standard deviation of the relative price change for the } 360 \text { calendar days closing price, } \\
\text { expressed as a percentage. }\end{array}$ \\
\hline BETA & The market model beta for each stock measured via the market model using weekly data. \\
\hline ROA & The return on assets measured as net income divided by total assets. \\
\hline GAAP & $\begin{array}{l}\text { A dummy variable that takes the value of } 1 \text { if the country applies US accounting standards or } \\
\text { international financial reporting standards (IFRS) and } 0 \text { otherwise. }\end{array}$ \\
\hline INDUSTRY & A dummy variable that takes the value of 1 for the relevant industry and 0 otherwise. \\
\hline CGOV & $\begin{array}{l}\text { A governance index developed using the principal component analysis. It is the first principal } \\
\text { component of all corporate governance indicators at country level except the control of corruption } \\
\text { indicator. }\end{array}$ \\
\hline GDP & The gross domestic product per capita. \\
\hline
\end{tabular}


Table 2: A breakdown of the sample by country

\begin{tabular}{|c|c|c|c|c|}
\hline Country & Obs. & NOA & CPI & GDP \\
\hline Australia & 230 & 15 & 81 & 53363 \\
\hline Austria & 24 & 23 & 80 & 47571 \\
\hline Belgium & 54 & 22 & 73 & 44509 \\
\hline Bermuda & 4 & 19 & 71 & 83752 \\
\hline Brazil & 12 & 12 & 38 & 11483 \\
\hline Britain & 583 & 22 & 77 & 39742 \\
\hline Canada & 273 & 20 & 82 & 48987 \\
\hline Chile & 25 & 12 & 68 & 13969 \\
\hline China & 42 & 29 & 24 & 5533 \\
\hline Denmark & 30 & 28 & 85 & 58894 \\
\hline Finland & 42 & 26 & 87 & 45972 \\
\hline France & 270 & 27 & 70 & 41265 \\
\hline Germany & 168 & 34 & 78 & 44138 \\
\hline Greece & 30 & 14 & 47 & 23593 \\
\hline Hong Kong & 65 & 20 & 75 & 34574 \\
\hline Ireland & 35 & 20 & 77 & 50183 \\
\hline Italy & 105 & 26 & 54 & 34713 \\
\hline Japan & 821 & 15 & 74 & 45701 \\
\hline Luxembourg & 12 & 26 & 83 & 104425 \\
\hline Mexico & 28 & 13 & 35 & 9235 \\
\hline Netherlands & 78 & 29 & 83 & 50550 \\
\hline Norway & 30 & 28 & 87 & 88442 \\
\hline Portugal & 24 & 16 & 63 & 21830 \\
\hline Singapore & 35 & 24 & 77 & 49716 \\
\hline South Africa & 6 & 23 & 45 & 7534 \\
\hline South Korea & 44 & 42 & 61 & 23624 \\
\hline Spain & 89 & 30 & 61 & 29898 \\
\hline Sweden & 134 & 24 & 86 & 53156 \\
\hline Switzerland & 153 & 27 & 86 & 75056 \\
\hline United States & 2442 & 21 & 74 & 49791 \\
\hline Grand Total & 5888 & 22 & 74 & 46851 \\
\hline
\end{tabular}


Table 3: Descriptive Analysis for Variables

\begin{tabular}{|c|c|c|c|c|c|c|c|c|c|c|c|c|c|}
\hline & NOA & $A B P$ & CPI & NINST & INST & INSID & MCAP & VOL & SEG & BETA & ROA & GAAP & GDP \\
\hline \multicolumn{14}{|l|}{ Panel A: } \\
\hline Mean & 21.59 & 0.62 & 74.30 & 633.35 & 66.43 & 1.34 & 28361.17 & 31.47 & 3.86 & 1.05 & 4.70 & 0.89 & 46851.33 \\
\hline Median & 21.00 & 0.70 & 74.37 & 498.50 & 70.43 & 0.23 & 13577.58 & 28.62 & 3.00 & 1.02 & 3.93 & 1.00 & 48455.21 \\
\hline $\begin{array}{l}\text { Std. Dev. } \\
\text { Panel B: }\end{array}$ & 8.85 & 0.24 & 8.00 & 492.07 & 25.99 & 4.13 & 45079.35 & 13.69 & 2.66 & 0.30 & 6.52 & 0.31 & 9907.94 \\
\hline NOA & 1.000 & & & & & & & & & & & & \\
\hline ABP & $0.399^{a}$ & 1.000 & & & & & & & & & & & \\
\hline CPI & -0.005 & $0.048^{a}$ & 1.000 & & & & & & & & & & \\
\hline NINST & $0.389^{a}$ & $0.253^{\mathrm{a}}$ & $0.038^{\mathrm{a}}$ & 1.000 & & & & & & & & & \\
\hline INST & $-0.029^{b}$ & $0.097^{a}$ & $0.092^{\mathrm{a}}$ & $0.357^{a}$ & 1.000 & & & & & & & & \\
\hline INSID & 0.017 & $-0.063^{a}$ & -0.004 & 0.013 & -0.012 & 1.000 & & & & & & & \\
\hline MCAP & $0.409^{a}$ & $0.291^{a}$ & $-0.056^{a}$ & $0.614^{\mathrm{a}}$ & $-0.080^{\mathrm{a}}$ & -0.014 & 1.000 & & & & & & \\
\hline VOL & $-0.115^{a}$ & $-0.275^{a}$ & $-0.178^{a}$ & $-0.328^{a}$ & $-0.089^{a}$ & -0.011 & $-0.231^{a}$ & 1.000 & & & & & \\
\hline SEG & $0.097^{a}$ & $0.024^{c}$ & $0.022^{c}$ & $0.061^{\mathrm{a}}$ & $-0.200^{a}$ & $-0.106^{a}$ & $0.166^{a}$ & $-0.056^{a}$ & 1.000 & & & & \\
\hline BETA & 0.010 & $-0.061^{a}$ & -0.008 & $-0.059^{a}$ & $0.105^{a}$ & 0.018 & $-0.120^{a}$ & $0.534^{a}$ & $0.038^{a}$ & 1.000 & & & \\
\hline ROA & $0.100^{\mathrm{a}}$ & $0.082^{\mathrm{a}}$ & $0.060^{\mathrm{a}}$ & $0.234^{a}$ & $0.148^{a}$ & $0.104^{a}$ & $0.193^{a}$ & $-0.309^{a}$ & $-0.154^{a}$ & $-0.227^{a}$ & 1.000 & & \\
\hline GAAP & $0.292^{\mathrm{a}}$ & $0.550^{\mathrm{a}}$ & $0.023^{c}$ & $0.263^{\mathrm{a}}$ & $0.311^{\mathrm{a}}$ & $0.069^{a}$ & $0.126^{\mathrm{a}}$ & $-0.075^{a}$ & $-0.131^{a}$ & $0.042^{\mathrm{a}}$ & $0.112^{\mathrm{a}}$ & 1.000 & \\
\hline GDP & -0.001 & 0.002 & $0.724^{\mathrm{a}}$ & $0.191^{\mathrm{a}}$ & $0.125^{a}$ & $0.033^{a}$ & 0.004 & $-0.130^{a}$ & 0.010 & $0.088^{a}$ & $0.042^{\mathrm{a}}$ & $0.042^{\mathrm{a}}$ & 1.000 \\
\hline
\end{tabular}

$\mathrm{N}=5,888$ firm-year observations. Superscripts a, b, c: correlations are significant at the $0.01,0.05$ and 0.10 levels (2-tailed) respectively. 
Table 4: Method: ML - Negative Binomial Count (Quadratic hill climbing) with

QML

(Huber/White) standard errors \& covariance

Dependent variable: Number of analysts following (NOA)

\begin{tabular}{|l|c|c|c|c|}
\hline & \multicolumn{2}{|c|}{ One estimated variable* } & \multicolumn{2}{c|}{ Two estimated variables** $^{*}$} \\
\hline$B_{\boldsymbol{O}}$ & $1.460^{\mathrm{a}}$ & $1.362^{\mathrm{a}}$ & $-1.432^{\mathrm{a}}$ & $1.917^{\mathrm{a}}$ \\
\hline ABP & $0.126^{\mathrm{a}}$ & 0.276 & $0.164^{\mathrm{a}}$ & $-6.984^{\mathrm{a}}$ \\
\hline CPI & $-0.007^{\mathrm{a}}$ & $-0.006^{\mathrm{c}}$ & $0.034^{\mathrm{a}}$ & -0.011 \\
\hline ABP*CPI & & -0.002 & & $0.097^{\mathrm{a}}$ \\
\hline NINST & $5.33 \mathrm{E}-05^{\mathrm{a}}$ & $5.29 \mathrm{E}-05^{\mathrm{a}}$ & $7.53 \mathrm{E}-05^{\mathrm{a}}$ & $8.20 \mathrm{E}-05^{\mathrm{a}}$ \\
\hline INST & $-3.52 \mathrm{E}-04$ & $-3.41 \mathrm{E}-04$ & $-5.27 \mathrm{E}-04^{\mathrm{b}}$ & $-5.48 \mathrm{E}-04^{\mathrm{b}}$ \\
\hline INSID & $-1.74 \mathrm{E}-03$ & $-1.76 \mathrm{E}-03$ & $-1.44 \mathrm{E}-04$ & $-4.16 \mathrm{E}-04$ \\
\hline LOG(MCAP) & $0.177^{\mathrm{a}}$ & $0.177^{\mathrm{a}}$ & $0.161^{\mathrm{a}}$ & $0.159^{\mathrm{a}}$ \\
\hline VOL & 0.001 & 0.001 & $0.001^{\mathrm{c}}$ & $0.001^{\mathrm{c}}$ \\
\hline SEG & $-0.004^{\mathrm{c}}$ & $-0.004^{\mathrm{c}}$ & -0.002 & -0.002 \\
\hline BETA & $0.131^{\mathrm{a}}$ & $0.131^{\mathrm{a}}$ & $0.081^{\mathrm{a}}$ & $0.078^{\mathrm{a}}$ \\
\hline ROA & $-0.004^{\mathrm{a}}$ & $-0.004^{\mathrm{a}}$ & $-0.003^{\mathrm{a}}$ & $-0.003^{\mathrm{a}}$ \\
\hline GAAP & $0.322^{\mathrm{a}}$ & $0.322^{\mathrm{a}}$ & $0.327^{\mathrm{a}}$ & $0.317^{\mathrm{a}}$ \\
\hline COMMUNICATIONS & $0.152^{\mathrm{a}}$ & $0.152^{\mathrm{a}}$ & $0.153^{\mathrm{a}}$ & $0.151^{\mathrm{a}}$ \\
\hline INDUSTRIAL & 0.013 & 0.013 & -0.004 & -0.004 \\
\hline DIVERSIFIED & $-0.364^{\mathrm{a}}$ & $-0.359^{\mathrm{a}}$ & $-0.546^{\mathrm{a}}$ & $-0.528^{\mathrm{a}}$ \\
\hline ENERGY & $0.150^{\mathrm{a}}$ & $0.149^{\mathrm{a}}$ & $0.133^{\mathrm{a}}$ & $0.133^{\mathrm{a}}$ \\
\hline TECHNOLOGY & $0.202^{\mathrm{a}}$ & $0.202^{\mathrm{a}}$ & $0.195^{\mathrm{a}}$ & $0.197^{\mathrm{a}}$ \\
\hline UTILITIES & $-0.097^{\mathrm{a}}$ & $-0.097^{\mathrm{a}}$ & $-0.109^{\mathrm{a}}$ & $-0.112^{\mathrm{a}}$ \\
\hline BASIC MATERIALS & $0.114^{\mathrm{a}}$ & $0.114^{\mathrm{a}}$ & $0.067^{\mathrm{a}}$ & $0.066^{\mathrm{a}}$ \\
\hline CONSUMER CYCLICAL & $0.101^{\mathrm{a}}$ & $0.101^{\mathrm{a}}$ & $0.079^{\mathrm{a}}$ & $0.082^{\mathrm{a}}$ \\
\hline CONSUMER NONCYCLICAL & -0.029 & -0.029 & -0.012 & -0.012 \\
\hline CGOV & $0.044^{\mathrm{a}}$ & $0.044^{\mathrm{a}}$ & $0.007^{\mathrm{b}}$ & $0.007^{\mathrm{b}}$ \\
\hline GDP & $-3.09 \mathrm{E}-06^{\mathrm{a}}$ & $-3.08 \mathrm{E}-06^{\mathrm{a}}$ & $-2.78 \mathrm{E}-06^{\mathrm{a}}$ & $-2.93 \mathrm{E}-06^{\mathrm{a}}$ \\
\hline Adjusted R-Squared & 0.40 & 0.40 & 0.39 & 0.39 \\
\hline Log likelihood & -13021.92 & -13021.79 & -19742.91 & -19728.39 \\
\hline ObS. & 3897 & 3897 & 5888 & 5888 \\
\hline SUPS & & & & \\
\hline
\end{tabular}

Superscripts a, b, c: coefficients are significant at the $0.01,0.05$ and 0.10 levels (2-tailed) respectively. *: ABP is estimated using instrumental variables. **: both $\mathrm{ABP}$ and $\mathrm{CPI}$ are estimated using instrumental variables. 